\title{
Location Types of Enterprise R\&D Institutions in Shanghai
}

\section{Nana}

Graduate School of Humanities and Sciences, Nara Women's University, Nara 630-8506, Japan.

E-mail: im_sailing@hotmail.com

Received May 10, 2011; Accepted January 19, 2012

\begin{abstract}
This article aims to discuss the location types and location patterns of the R\&D institutions of manufacturing enterprises in Shanghai. Such R\&D institutions are classified into four location types according to the location relationship between them and other organizations: Headquarters-Production type, Headquarters type, Production type, and Independent type, among which the Headquarters-Production type is the most common. Most R\&D institutions are concentrated in industrial zones or hi-tech parks. However, there are differences in industry and location pattern among the various types of R\&D institutions. The Headquarters-Production and Production types are most common in the equipment and chemical industries with a wide distribution throughout the surburbs. The location patterns of the Headquarters and Independent types are similar: they are most common in the industrial zones near the central city. Various location factors lead to the diversity in location types and patterns seen in R\&D institutions. Enterprises pay great attention to the need for all of their organizations to cooperate when establishing $R \& D$ institutions. As an enterprise grows, organizational separation is inevitable, leading to a variety of R\&D location types. In this process, limited land scale and rising land costs in urban cities become important factors that accelerate the surburbanization of $\mathrm{R} \& \mathrm{D}$ institutions. Furthermore, the need for human resources, and the well-developed transport systems and communication networks in Shanghai make it unnecessary to be close to local universities or research institutes. In addition, regional image has also aroused concern and has become an important factor in the choice of R\&D location.
\end{abstract}

Key words enterprise R\&D institution, location type, location pattern, location factor, Shanghai

\section{Introduction}

Research and development (R\&D) is important for economic growth. As institutions that spearhead most R\&D activities, $R \& D$ institutions ${ }^{1}$ contribute positively to regional economic development through direct contributions to the local economy and the spillover effects on the local industry and other companies. Thus, $R \& D$ (1) creates economic efficiency directly by building R\&D institutions, (2) produces spillover effects on regional industries through $\mathrm{R} \& \mathrm{D}$ activities and economic revitalization through the commercialization of $R \& D$ results, and (3) has beneficial effects on other firms by locating $R \& D$ institutions nearby, performing $R \& D$ activities and developing business relationships among firms (Osaka Prefecture Institute for Advanced Industrial Development 2007). Enterprises play particularly decisive roles in innovation and knowledge spillovers through their R\&D activities. Moreover, R\&D activities implemented by enterprises not only promote national science and technology, but also strengthen their country's global economic influence. As a result, $R \& D$ institutions have grown rapidly not only in developed countries such as the USA and Japan, but also in developing countries such as China and India.
Concurrently, we can observe strong tendencies in R\&D globalization (Florida 1997; Cantwell 1995), along with the strong spatial clustering of R\&D and related innovation activities (Audretsch and Feldman 1996). Studies on the location of $R \& D$ institutions have aroused concern in the field of economic geography, with extant studies on enterprise $\mathrm{R} \& \mathrm{D}$ concentrating mainly on multinational corporations (MNCs), because they are the main contributors to long-term R\&D activity. Previous overseas studies have focused on two issues: (1) the organizational network characteristics of MNCs' R\&D activity and the location changes of MNCs' R\&D institutions (Robert 1977; Kuemmerle 1999; Sun 2003; Dunning 2000); (2) location factors for MNCs' R\&D institutions (Niosi 2003).

Research in $\mathrm{R} \& \mathrm{D}$ on a national scale has also been on the rise lately. Leonard (1986) points out that the five leading R\&D location factors in order of priority are proximity to headquarters, abundant research personnel, high quality of life and complete community facilities, proximity to the production plant, and proximity to universities and research institutes. Access to the users of new products is also very important for getting timely feedback about a product's function and consumer preferences. Nakagawa (1996) points out that the majority 
of Japanese R\&D institutions are highly concentrated in Tokyo and the surrounding areas and that nearly $40 \%$ of $\mathrm{R} \& \mathrm{D}$ institutions are attached to the headquarters of their respective firms. Although $\mathrm{R} \& \mathrm{D}$ institutions in Japan were once decentralized away from metropolitan areas towards external metropolitan areas, they have now returned to the metropolitan areas (Ishigami 1986; Sato 2004; MLIT 2006). Furthermore, land factors (e.g., land scale), the organization of the enterprise (e.g., its proximity to headquarters and other departments), and its surroundings (e.g., its proximity to human and information sources) have a great impact on the location and relocation of R\&D institutions (Oda and Saso 1987; Kato et al. 1996; Sato 2004; Nakagawa et al. 1992).

In examining the types of $\mathrm{R} \& \mathrm{D}$ activity, an important research question is how an R\&D institution's choice of objectives is conditioned by its research or development orientation. Creamer (1976) and Pearce (1989) identified three primary types of R\&D activity: basic research, applied research, and development activities. Another perspective is framed by the motives for establishing R\&D institutions. Du (2001) classifies the location models of overseas MNCs' R\&D institutions into three types: Production-supporting, Technology-tracking and Resource-seeking. He points out that the Productionsupporting type is generally found in countries with huge markets and is usually located close to existing factory sites. The location of the Technology-tracking type is most strongly influenced by the competitiveness and science and technology levels of the host country, and thus, favors nations or regions with high levels of technology. The Resource-seeking type is preferably located in regions with an abundance of talent. Nakagawa (1996) divides $\mathrm{R} \& \mathrm{D}$ institutions into the following categories based on their industrial features: basic materials (e.g., chemicals industry, petroleum, coal, and electrical machinery), life related (e.g., food, fiber, and press), information-services (e.g., information services, research, development and testing), as well as other types, fishery, forestry, construction, transport and communication, for example, and points out that location patterns differ across types.

China is the fastest growing economy in Asia and remains the top-ranked destination for foreign investors, a status it has held since 2002 (A.T. Kearney Global Business Policy Council 2010). Geographic studies on enterprise $\mathrm{R} \& \mathrm{D}$ institutions in China started in the 1990s, the majority concentrating on R\&D's locations and location factors of MNCs and Foreign Direct Investment (FDI ) (Xue et al. 2002; Zhang and Du 2006; Wang and $\mathrm{Du}$ 2007). R\&D institutions in China are concentrated in eastern China, with most such facilities being located in industrial parks. Although R\&D institutions have also recently increased in western China, eastern coastal cities (especially Shanghai, Beijing and Shenzhen ${ }^{2}$ ) remain the main destinations for MNCs' R\&D facilities, with Shanghai being a more attractive destination than other cities (Liu and Liu 2007; Du et al. 2010). There is a distinct spatial differentiation among MNCs' R\&D institutions according to industry and home country. The R\&D-related investments by MNCs in Beijing flow largely from the electronic communications industry, whereas those in Shanghai mainly come from the chemical biology industry. American-origin R\&D is mainly from the electronics and communication industry, and most of them are located in the Yangtze River Delta region (centered in Shanghai) and Bohai Rim (centered in Beijing). In contrast, almost all European R\&D is concentrated in the Yangtze River Delta region, as is the R\&D investment from Japan (Du et al. 2010). Du (2001) points out that the most important factors attracting MNCs R\&D investment to China are the huge market potential and the abundant and cheap $\mathrm{R} \& \mathrm{D}$ talent. Complete infrastructure and an active economy also have positive effects on R\&D activities. While absorptive capacity for FDI is important, market potential and human capital are also regarded as key factors in the regional differentiation among MNCs R\&D in China (He and Wang 2006).

Previous studies on R\&D institutions in China and abroad have something in common: both focus on the location of R\&D institutions. However, previous Chinafocused studies have concentrated on the distribution of R\&D institutions and location factors at the national-level, but have failed to provide detailed local-level analyses of regions or cities or of firms' heterogeneity. In addition, despite the abundant literature on R\&D in China, most literature concerns MNCs, while literature discussing enterprise $\mathrm{R} \& \mathrm{D}$ institutions from the perspective of domestic capital, in contrast, is very limited.

Against this background, this article attempts to explore the location features of $\mathrm{R} \& \mathrm{D}$ institutions of Chinese enterprises at the local level. As it is well known that R\&D activities are highly concentrated in metropolitan and surrounding areas, this paper uses Shanghai as the study area. In the Special Investigations of Enterprise Innovation 2006 (National Bureau of Statistics of China 2006), more than half of the surveyed enterprises take innovation very seriously and regard Shanghai as the most favorable city in China for R\&D institutions, followed by Beijing, Hangzhou $^{3}$, Qingdao ${ }^{4}$, Shenzhen, and Suzhou ${ }^{5}$. Some 
of the literature has recently focused on the location of enterprise $\mathrm{R} \& \mathrm{D}$ institutions in Shanghai $(\mathrm{Xu}$ and $\mathrm{Du}$ 2004; Dong 2007; Wang 2007). Findings from previous studies show that despite the decentralization of R\&D institutions from central city to the suburbs, most are concentrated in a few industrial zones and high-tech parks. High-tech parks attract R\&D investment owing to their favorable locations, while rising land costs in central city areas accelerate the movement of R\&D institutions from central city to the suburbs (Dong 2007). In analyzing the location types of enterprise $R \& D$ institutions in Shanghai, Wang (2007) studied R\&D institutions of FDI from three different perspectives: (1) the function of R\&D, (2) location relationships between the R\&D institutions and other organizations, and (3) location characteristics of the R\&D institutions' sites. However, these studies pay much more attention to the MNC and FDI-founded R\&D institutions than to those funded by domestic enterprises. Further, these studies are only descriptive, lacking any detailed or deep analyses of the location features for different types of R\&D institutions.

Firm-specific characteristics underlie R\&D location choices. Large companies, R\&D labs, and single-plant firms are not attracted by the same local features. This is particularly important for regions, whose attractiveness varies according to the characteristics of a firm (AutantBerard 2006). The location of R\&D institutions varies greatly according to industry, enterprise, geographical location and historical background. It is not necessary to locate the R\&D institution, management, production plant and market department in the same location in order to maximize profit (Porter 1986). One can locate $R \& D$ institutions attached to other organizations to create an integrated management structure or allocate specialized $\mathrm{R} \& \mathrm{D}$ institutions to various departments to achieve specialization (Nishioka and Matsuhashi 1990). Moreover, a regional differentiation in production occurs during industrial transfers to surrounding metropolitan areas and regions, and various $R \& D$ location features are shaped through the filtering process (Kimura 1990). Therefore, it is important to do further study on enterprise $R \& D$ institutions from the perspective of enterprises' organizational location relationships and to take into account their heterogeneity. This article aims to explore the location types of enterprise R\&D institutions in Shanghai in terms of the location relationships between R\&D institutions and other organizations within an enterprise, and perform detailed analyses on the location features of enterprise R\&D institutions according to their different types, keeping domestic enterprises as the main study target.

\section{Overview of Shanghai and Study Method}

Shanghai is the most populous city in China: the 2010 census revealed that the population had reached 23.02 million. The city sits at the mouth of the Yangtze River on China's eastern coast and is bordered on the north and west by Jiangsu Province, on the south by Zhejiang Province, and on the east by the East China Sea. The city is bisected by the Huangpu River, a tributary of the Yangtze. Shanghai is administratively equal to a province and is divided into 19 county-level districts ${ }^{6}$ (Figure 1 ), which are in turn grouped under three divisions according to their distance from the central area: the central city, inner suburban areas and the outer suburbs. Shanghai's central city includes Huangpu, Luwan, Xuhui, Changning, Jingan, Putuo, Zhabei, Hongkou and Yanagpu, all of which are inside the outer ring road, and the part of the Pudong New Area which is located inside the inner ring road. The inner suburban areas, adjoining the central city, include Minhang, Jiading, Baoshan and the other part of the Pudong New Area. The outer suburbs include Chongming County, Nanhui, Fengxian, Jinshan, Songjiang and Qingpu. Because of its rapid growth over the last two decades, Shanghai has once again become one of the world's leading cities, exerting influence over finance, commerce, fashion and culture.

In 2006, R\&D expenditures in Shanghai, among which almost $75.5 \%$ came from large and mediumsize industrial enterprises ${ }^{7}$, reached 17.6 billion yuan, accounting for $68 \%$ of the total $\mathrm{R} \& \mathrm{D}$ expenditure in Shanghai and proving that large and medium-size industrial enterprises are the main contributors to $R \& D$ activity (Lin et al. 2007). As Figure 2 indicates, science and technology personnel have a higher presence in larger and medium industrial enterprises than in universities and research institutes. Moreover, most of these industrial enterprises' science and technology institutions are highly concentrated in manufacturing (Table 1), with the highest proportion in chemicals and chemical products (15.2\%), followed by communications, computing and other electronic equipment (14.9\%), transportation equipment (11.5\%), electrical machinery and equipment (13.2\%), general equipment (7.9\%), and medicine (7.3\%).

Through empirical analysis, this article explores the location types and patterns of enterprise R\&D institutions. The sample database comes from Entrepreneurship, innovation and creation: Report on Shanghai's private enterprises' innovation (Shanghai Private Economy 


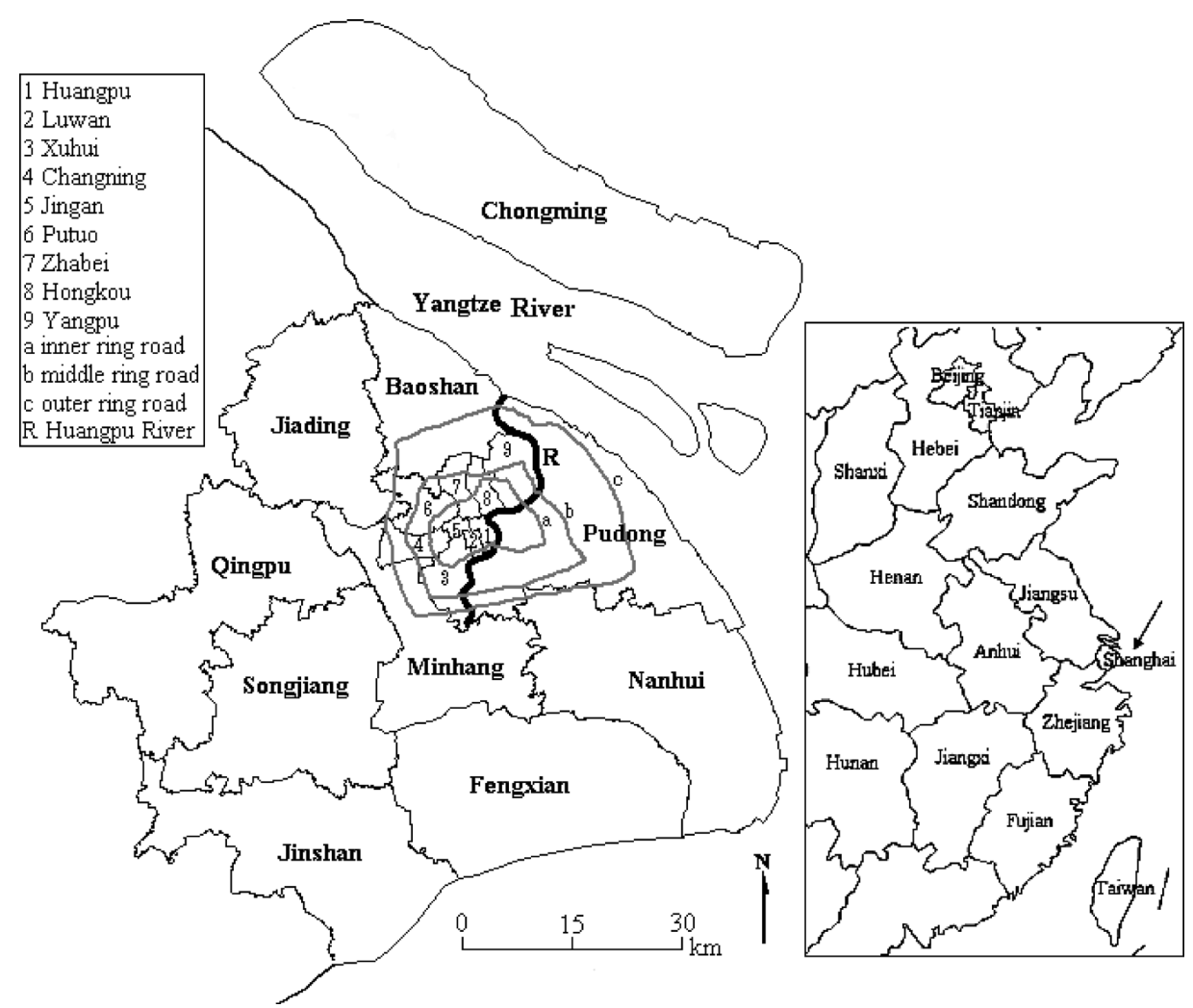

Figure 1. Administrative map of Shanghai.

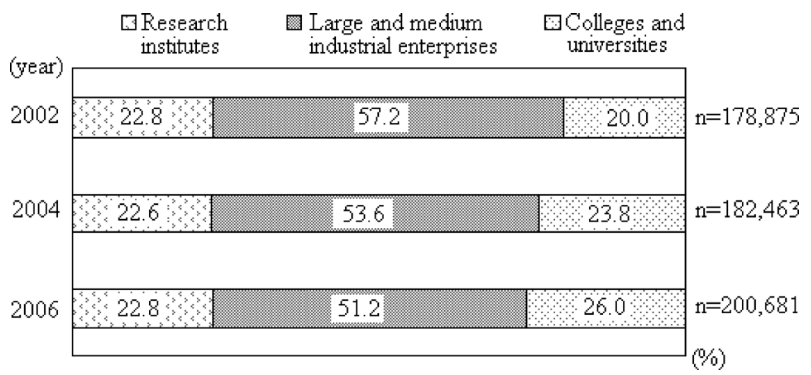

Figure 2. Science and Technology personnel in Shanghai by institution.

Source: Lin et al. 2007.

Development and Promotion Center 2006) and a website about Shanghai enterprise R\&D institutions. Profiles on innovation achieved by private enterprises in the equipment, information, chemical and pharmaceutical, and other rising industries are provided in the above mentioned book, as are some of the samples used in this article. However, these profiles are too simple to provide detailed information on enterprises' R\&D and include only private enterprises. Therefore, to get as much data as possible, other samples were collected from websites on Shanghai enterprise R\&D institutions. Moreover, because most previous studies have focused on MNCs, we take domestic enterprises as the main study samples in this article. By collecting samples, we obtained a preliminary data set of 191 enterprise R\&D institutions. Then, we verified the collected data by phone and email verification,
Table 1. Industrial features of S\&T institutions in large and medium-sized industrial enterprises of Shanghai (2006)

\begin{tabular}{|l|r|r|}
\hline \multicolumn{1}{|c|}{ Industry } & $\begin{array}{r}\text { Number of the } \\
\text { S\&T Institutions }\end{array}$ & $\begin{array}{r}\text { Personnel in } \\
\text { S\&T Institutions }\end{array}$ \\
\hline Chemicals and Chemical Products & 54 & 1,524 \\
\hline $\begin{array}{l}\text { Communication, Computer and } \\
\text { Other Electronic Equipment }\end{array}$ & 53 & 6,807 \\
\hline Transportation Equipment & 41 & 6,326 \\
\hline Electrical Machinery and Equipment & 47 & 2,068 \\
\hline General Equipment & 28 & 2,727 \\
\hline Pharmaceutical and Medicine & 26 & 709 \\
\hline Others & 106 & 4,840 \\
\hline Total & 355 & 25,001 \\
\hline
\end{tabular}

Note: S\&T denotes Science and Technology.

Source: Lin et al. 2007.

targeting the 191 enterprises to increase the reliability of the obtained data. This process produced 92 valid data, comprising 91 enterprises (the enterprise which has two $\mathrm{R} \& \mathrm{D}$ institutions is included). Among these 92 enterprise R\&D institutions, 81 are in manufacturing, 7 in software, 3 in finance, and 1 in environmental management.

Based on the surveys, the following part is organized in three sections. The first section presents the spatial distribution characteristics and industrial features of 92 sample R\&D institutions. The second section analyzes 


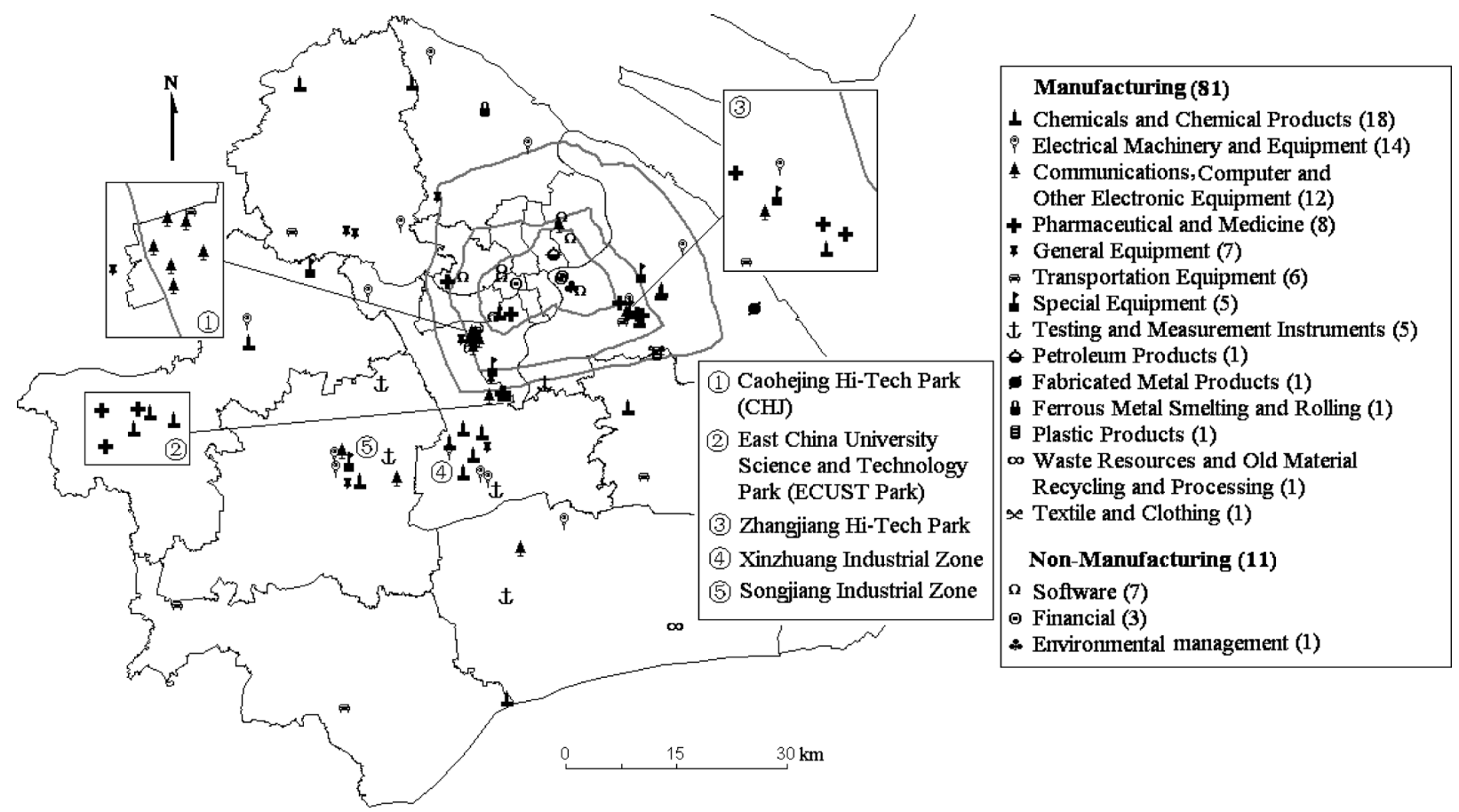

Figure 3. Distribution of enterprise R\&D institutions.

Note: The sample enterprise R\&D institutions in this figure include 65 of domestic enterprises, 15 governed by foreign capital and one founded by sino-joint ventures.

Source: Author's Survey.

the location types of enterprise R\&D institutions from the perspective of the location relationship between them and other organizations. As most sample enterprise R\&D institutions are in manufacturing $(88.8 \%)$, the samples in this section are restricted to the $81 \mathrm{R} \& \mathrm{D}$ institutions from manufacturing, including 65 enterprises using Chinese capital, 15 enterprises using foreign capital and one Sinoforeign joint venture. Based on an analysis of location types, this section also examines the location patterns and industrial features of these institutions according to their different location types. In the third section, we explore the factors influencing the location of manufacturing enterprise $\mathrm{R} \& \mathrm{D}$ institutions at the local level through case studies involving different location types and industries.

\section{Location Types of Enterprise R\&D Institutions in Shanghai}

\section{Spatial distribution of enterprise R\&D institutions}

Of the $92 \mathrm{R} \& \mathrm{D}$ institutions, the largest number are in the chemical and chemical products industries (18, 19.6\%), followed by electrical machinery and equipment $(14,15.2 \%)$, communications equipment, computer and other electronic equipment (12, 13\%), and pharmaceutical and medical $(8,8.7 \%)$ industries. Figure 3 shows the distribution of the 92 enterprise R\&D institutions. It shows that the non-manufacturing $R \& D$ institutions are all located in the core areas of the central city. In contrast, the R\&D institutions of manufacturing enterprises are distributed among various districts from the central city to the suburbs. Meanwhile, although the decentralization of the R\&D institutions of manufacturing enterprises is obvious, industrial zones and hi-tech parks have become popular areas for enterprise $R \& D$ institutions, accounting for 52 of them, representing $64.2 \%$ of the total for manufacturing, particularly being concentrated in Caohejing Hi-Tech Park $(\mathrm{CHJ})^{8}$, East China University Science and Technology Park (ECUST Park) ${ }^{9}$, Zhangjiang Hi-Tech Park ${ }^{10}$, Xinzhuang Industrial Zone ${ }^{11}$ and Songjiang Industrial Zone ${ }^{12}$. It can also be seen from Figure 3 that the R\&D institutions in different industries show regional differences. R\&D institutions in the chemicals and chemical products industry are mainly located in ECUST Park and the Xinzhuang Industrial Zone in the middle and south of Shanghai; the R\&D institutions in the communications and computer and other electronic equipment industries are concentrated in $\mathrm{CHJ}$; most of the R\&D institutions in the pharmaceutical and medicine industries are in ECUST Park and Zhangjiang Hi-Tech Park, whereas the $R \& D$ institutions in other industries are scattered throughout the suburban areas. This spatial pattern is conditioned by the development process and strategy of each industrial zone and hi-tech park. For example, 


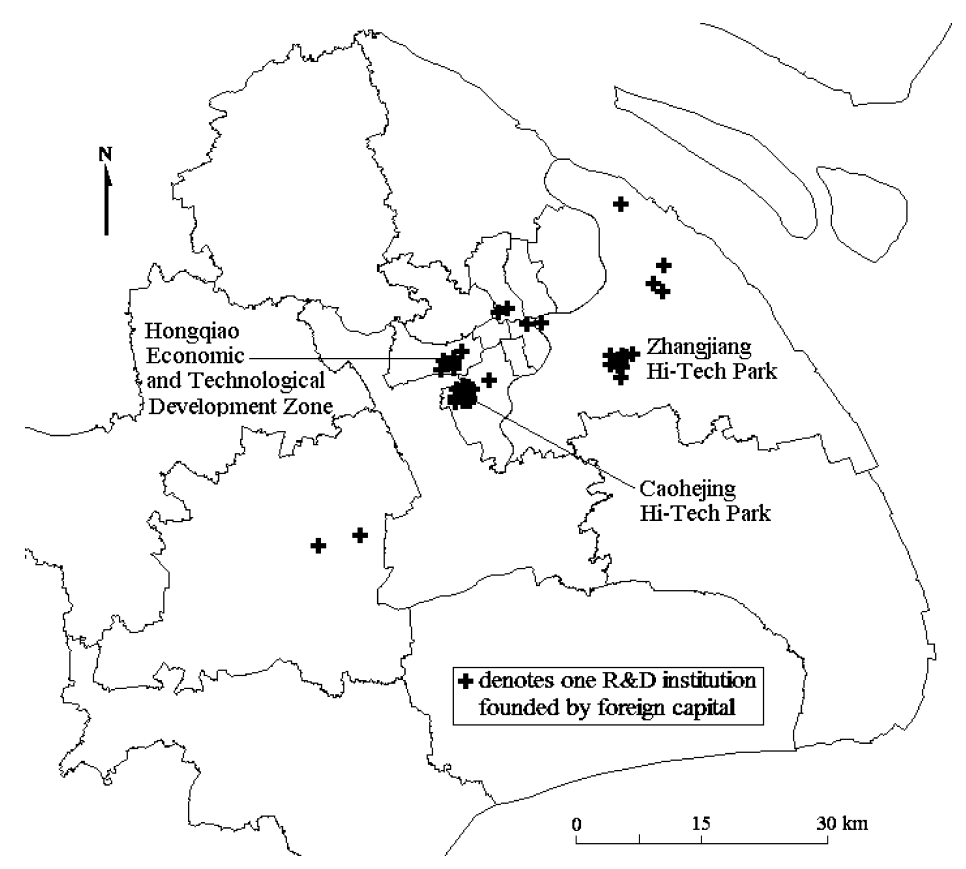

Figure 4. Distribution of enterprise R\&D institutions founded by foreign capital.

Source: Xu and Du 2004.

the earliest embryonic form of $\mathrm{CHJ}$ is "Caohejing Microelectronics Industrial Park", which was established in 1984 for the purpose of attracting foreign investment and advanced high technology. Then the upstream and down stream industries also followed on and thus companies from the industries of microelectronics, computer, communications, biomedicine and automobile are concentrated in $\mathrm{CHJ}$. Regarding Zhangjiang Hi-Tech Park, at the first stage of its establishment, the government issued a clear-cut instruction that biomedicine would be one of the leading industries in Zhangjiang Hi-Tech Park. In the following period, one part of Zhangjiang Hi-Tech Park, Zhangjiang biotech and pharmaceutical base known as "Zhangjiang Pharmaceutical Valley" was founded and has became one of the largest concentrations of pharmaceutical R\&D institutions in China.

A previous study (Xu and Du 2004) contains an analysis of the distribution of $R \& D$ institutions governed by foreign capital in Shanghai, allowing us to see the spatial similarities and differences between $\mathrm{R} \& \mathrm{D}$ institutions governed by domestic and foreign capital enterprises. Figure 4 shows that $\mathrm{R} \& \mathrm{D}$ institutions managed by foreign capital show a much higher concentration than those managed by domestic enterprises, especially high concentrations in $\mathrm{CHJ}$ and the Zhangjiang Hi-Tech Park inside the outer ring road. Ever since the industrial zones and hi-tech parks were established, the government has built much infrastructure and has implemented a series of preferential policies to attract foreign investment and hi-tech enterprises, making industrial zones and hi- tech parks the preferred locations for foreign investors. Moreover, as the two most developed business parks, $\mathrm{CHJ}$ and Zhangjiang Hi-Tech Park are now amongst China's most high profile business parks and have become hot spots for foreign R\&D in Shanghai (Jones Lang LaSalle 2008).

\section{Location types of enterprise R\&D institutions in terms of location relationship between enterprise organizations}

To be profitable, business firms and forms of organizations are allocated territorially or regionally (Walker 1988). Companies organize the activities required for creating and selling products territorially or regionally and thus allocate these activities within their own enterprises and among the other firms with which they interact. Such managerial allocation of the steps involved in the production and sale of goods creates linkages of economic activity within and across firms (Fields 2006). R\&D institutions' locations and their location relationships with other inter-firm organizations can reflect an organizational distribution of economic activity. The location features that the enterprise $R \& D$ institutions form spatially and the relationship between these $R \& D$ institutions and other inter-firm organizations comprise the focus of this article.

According to the location relationships between R\&D institutions and other departments, the surveyed enterprise R\&D institutions are classified into four location types: (1) the same location ${ }^{13}$ as headquarters 
Table 2. Industry of enterprise R\&D institutions by location types

\begin{tabular}{|c|c|c|}
\hline Location Types & Industry & Remarks \\
\hline Headquarters-Production Type (42) & $\begin{array}{l}\text { Electronic Machinery and Equipment (9) } \\
\text { Chemicals and Chemical Products (8) } \\
\text { Special Equipment (5) } \\
\text { Communication Equipment, Computer and } \\
\text { Other Electronic Equipment (4) } \\
\text { General Equipment (4) } \\
\text { Testing and Measurement Instruments (4) } \\
\text { Transportation Equipment (3) } \\
\text { Others (5) }\end{array}$ & $\begin{array}{l}\text { Foreign-founded Enterprises (3) } \\
\text { Sino-foreign joint ventures (1) } \\
\text { Parent companies in cities other than Shanghai: } \\
\text { Zhejiang Province (3) }\end{array}$ \\
\hline Headquarters Type (16) & $\begin{array}{l}\text { Chemicals and Chemical Products (5) } \\
\text { Pharmaceutical and Medicine (4) } \\
\text { Communication Equipment, Computer and } \\
\text { Other Electronic Equipment (2) } \\
\text { Electronic Machinery and Equipment (2) } \\
\text { Others (3) }\end{array}$ & $\begin{array}{l}\text { Foreign-founded Enterprises (3) } \\
\text { Enterprises with their own production sector } \\
\text { (14) } \\
\text { Enterprises commissioning production in other } \\
\text { companies (2) }\end{array}$ \\
\hline Production Type (7) & $\begin{array}{l}\text { Chemicals and Chemical Products (2) } \\
\text { Electronic Machinery and Equipment (2) } \\
\text { General Equipment (2) } \\
\text { Transportation Equipment (1) }\end{array}$ & \\
\hline Independent Type (16) & $\begin{array}{l}\text { Communication Equipment, Computer and } \\
\text { Other Electronic Equipment (6) } \\
\text { Chemicals and Chemical Products (3) } \\
\text { Pharmaceutical and Medicine (3) } \\
\text { Others (4) }\end{array}$ & $\begin{array}{l}\text { Foreign-founded Enterprises (8) } \\
\text { Domestic Enterprise with headquarters in } \\
\text { Shanghai (1) } \\
\text { Domestic Enterprises with headquarters in cities } \\
\text { other than Shanghai (7): Beijing (2), Jiangsu } \\
\text { Province (2), Zhejiang Province (1), Shandong } \\
\text { Province (1), Guangdong Province (1) }\end{array}$ \\
\hline
\end{tabular}

Note: Numbers in brackets indicate the numbers of R\&D institutions.

Source: Author's Survey.

and production plant (Headquarters-Production type), (2) the same location as headquarters (Headquarters type), (3) the same location as production plant (Production type), and (4) independent location from other organizations (Independent type $\mathrm{e}^{14}$ ). There are 42 R\&D institutions of the Headquarters-Production type in the survey, accounting for the largest proportion (51.9\%), followed by the R\&D institutions of the Headquarters type (16, 19.8\%), Independent type (16, $19.8 \%)$, and Production type (7, 8.6\%), as summarized in Table 2. Apparently, most enterprises allocate R\&D institutions together with headquarters and productions. However, although production links are essential for enterprises in the manufacturing industry, more $R \& D$ institutions are allocated with headquarters than those with the production plant. Moreover, some enterprises of Headquarters type choose commission production in order to realize commercialization, despite the fact that related production activities are generally launched in their own production plants. There are 3 enterprises of the Headquarters-Production type with parent companies from domestic cities other than Shanghai, 8 enterprises of the Independent type run by foreign entities, and 7 run by domestic enterprises with headquarters in other cities. It is notable that among enterprises from domestic cities other than Shanghai, the enterprises from Zhejiang Province (which boarders Shanghai) are most numerous, and next is Jiangsu Province near Shanghai, indicating that geographical proximity is significant in the regional allocation of economic activities.

\section{Location patterns for different types of enterprise R\&D institutions}

The location patterns of $R \& D$ institutions vary according to the content of the R\&D and their location types differ according to the product and industry features (Nakagawa 1996). For example, company A (Figure 5) ${ }^{15}$, founded on a firm of actual electrical equipment manufacturing, produces high-voltage electrical equipment and related components. Two R\&D institutions are set up in company $A$ at different sites. One R\&D institution (A1), handling electronic components, is located at the same place as the headquarters, and the other one (A2), handling high-voltage electrical equipment, is established in a newly funded production base. Consequently, industrial differences across firms and product divisions within a single firm can result in a diversity of R\&D location types and patterns.

Headquarters-Production $R \& D$ institutions are concentrated in the chemicals and chemical products 


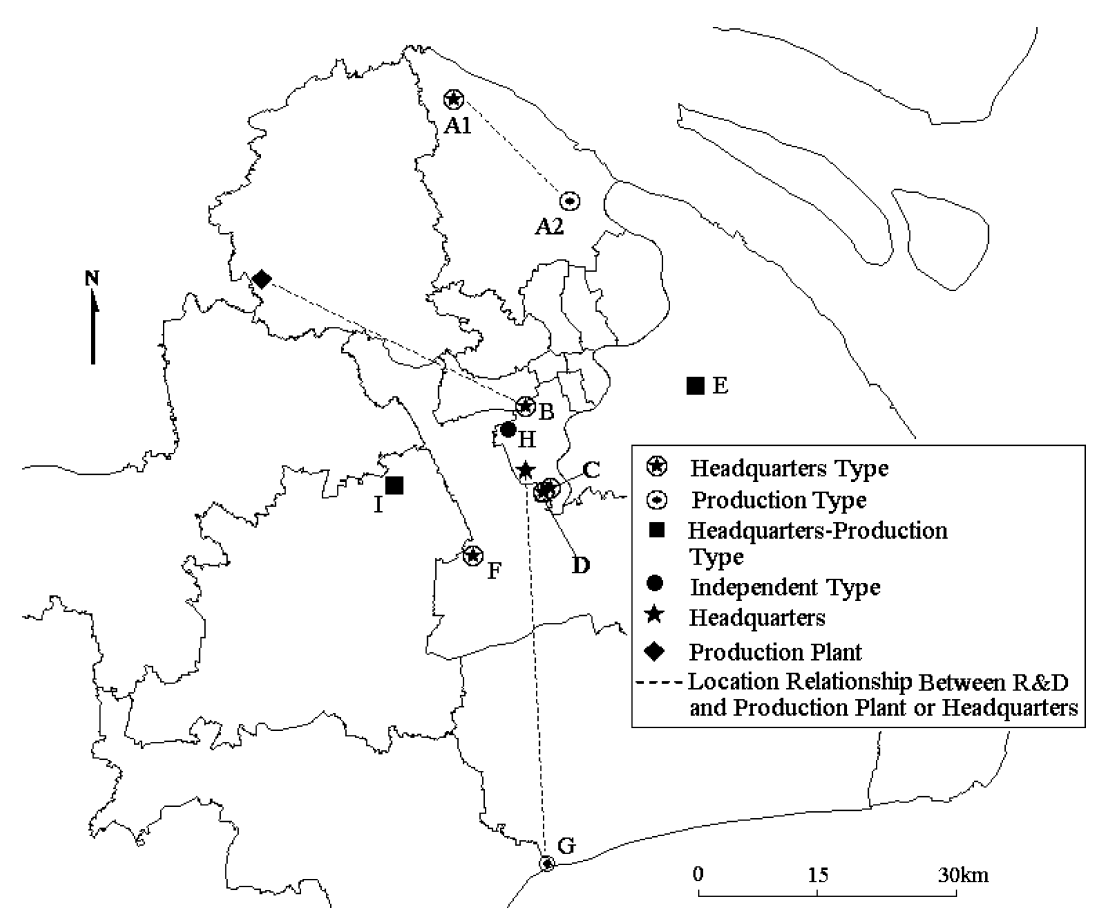

Figure 5. Location of case enterprise R\&D institutions.

Source: Author's Survey.

and equipment manufacturing industries (Table 2). These enterprises include many related upstream and downstream industries and are very sensitive to land cost; they are therefore inclined to be located in suburban areas (Figure 6-a). In addition to equipment manufacturing, a minority of R\&D institutions in other industries (such as pharmaceutical and medicine and waste resources and old material recycling and processing) are concentrated in ECUST Park. The products for those enterprises are more sensitive to market needs, and their land use scales are relatively smaller; they therefore prefer to be close to central areas with large markets.

Secondly, more than half of the Headquarters type R\&D institutions are in the chemicals and chemical products and pharmaceutical and medicine industries, followed by equipment manufacturing. As shown in Figure 6-b, these $\mathrm{R} \& \mathrm{D}$ institutions are primarily located in $\mathrm{CHJ}$ and ECUST Park in Xuhui District and Zhangjiang Hi-Tech Park in Pudong New Area. Moreover, among the 16 Headquarters type R\&D institutions, only 5 enterprises have established production plants in Shanghai, all being located in suburban areas outside the inner ring road, while all of the other production plants are in cities other than Shanghai.

Location allocation is a combinatorial optimization problem, which involves industrial features and product characteristics. Consequently, enterprises running Headquarters type R\&D will have production models adapted in different ways. According to the surveys, related enterprises with Headquarters type R\&D institutions are divided into two subtypes according to their production way. The first type is an enterprise with a fixed production site. In the case of company B (Figure 5 ), the $\mathrm{R} \& \mathrm{D}$ institution and production plants were initially located in $\mathrm{CHJ}$ together with its headquarters. As the enterprise grew, company B began to seek cheaper and larger land for its production site because the land available could not meet the needs of production expansion. Then, the production plant was transferred to its present site, Anting town in Jiading district (in the outer suburbs), while the $\mathrm{R} \& \mathrm{D}$ institution remained at the original site, together with the headquarters. Another example is company $\mathrm{C}$ being engaged in pharmaceutical production. Its headquarters and $\mathrm{R} \& \mathrm{D}$ institution are located in ECUST Park, whereas its production plant is set up in Hangzhou, near Shanghai. The second type is an enterprise with a non-fixed production site. An example of this type is company D. Its headquarters and R\&D institution are located in ECUST Park (in Xuhui district), but the production plant is located in another city of Changzhou $^{16}$, near Shanghai. Company D has established partner relationships with clients in Changzhou. It is not only easier and cheaper to lease production sites and equipment in Changzhou (thus generating cost savings), but also very helpful in strengthening communication with customers so that the products can reach them quickly. Usually, this type of enterprise begins with developing new products, and then seeks the proper 

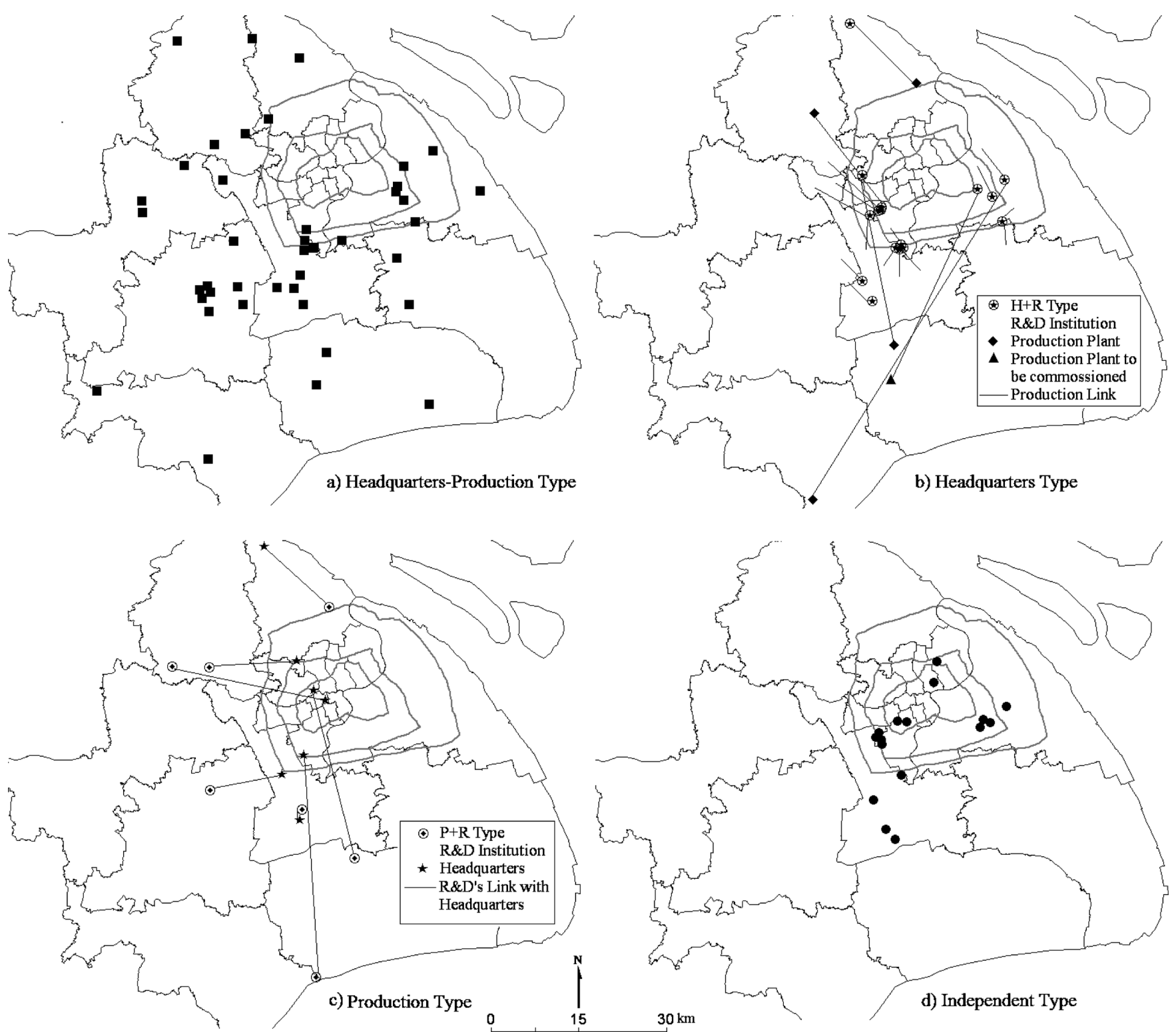

Figure 6. Location patterns for different types of enterprise R\&D institutions.

Note: The line without end point in figure b) denotes that the production plant is located in a city other than Shanghai. Source: Author's Survey.

production plant and performs secondary development once market feedback is received. Influenced by the rising land costs in urban areas, more enterprises are using this way to undertake R\&D activities and complete the commercialization of $\mathrm{R} \& \mathrm{D}$ results.

Production type R\&D institutions are the least common. Of the 7 Production type R\&D institutions, 5 are in equipment manufacturing (Table 2). For these industries, there are close links between production and R\&D activity and high demand for trial-production and production. In order to speed up the process from research and development to commercialization, the R\&D institutions tend to be close to the production plant. The decentralization of the Production type R\&D institutions into the outer suburbs is very obvious in Shanghai due to the need for large scale areas of land, whereas the headquarters are almost allocated in the central city (Figure 6-c).

Lastly, attention is turned to the Independent type institutions. They are separate from the headquarters and plants and generally engaged in R\&D activities aiming at providing $R \& D$ services to headquarters, plants, or other enterprises. Independent $R \& D$ institutions mainly occur in high-tech industries of communication equipment, computer and other electronic equipment, chemicals and chemical products, and pharmaceuticals and medicine (Table 2). Enterprises from these industries, for which product update speed is the key to competitiveness, put emphasis on the role of R\&D. They are extremely sensitive to market and technological changes and prefer areas 
with an active innovation atmosphere and advantageous locations. As shown in Figure 6-d, the majority of the Independent type R\&D institutions are located in areas inside the outer ring road, mostly concentrated in $\mathrm{CHJ}$, Xuhui district and Zhangjiang Hi-Tech Park, Pudong New Area.

As shown above, most domestic enterprises in Shanghai currently allocate headquarters, production sectors, and $\mathrm{R} \& \mathrm{D}$ institutions at the same location. Meanwhile, different location types and patterns occur as $R \& D$ institutions separate from other organizations. In the process of reallocating inter-firm departments territorially and regionally, $\mathrm{R} \& \mathrm{D}$ institutions usually become attached to headquarters, whereas a minority of the $R \& D$ institutions are located together with production plants, and many production sectors are transferred from Shanghai to other cities. Of course, this division of labor is not absolutely organizational and geographical, but rather industrial and social. In spatial terms, there are location similarities among the different types of R\&D institutions. Headquarters and Independent types have similar patterns, and most of them are located in areas near the central city, particularly in industrial zones and hi-tech parks (Figure 6-b and d). In addition, the decentralization of manufacturing enterprise $R \& D$ institutions to the suburbs is obvious, which is particularly evident for the Headquarters-Production and Production types of $R \& D$ institutions. It appears that it is only the transfer of manufacturing production away from the central city that leads to the geographical decentralization of R\&D activities, which can also bring about transformations in urban function and spatial structure.

\section{Location Factors for Enterprise R\&D Institutions in Shanghai}

This section focuses on the local-scale factors that condition the distribution of enterprise $\mathrm{R} \& \mathrm{D}$ institutions in Shanghai using the interview surveys towards sample enterprises. Shanghai's rich talent resources and relatively complete infrastructure are primary elements in the development of its R\&D activities. More and more enterprises realize that choosing Shanghai is helpful to seize the huge market of the Yangtze River Delta. However, each enterprise has its own concerns, and may lay emphasis on different factors at different stages. In order to explain enterprises' heterogeneity, we chose one enterprise from each type of R\&D institution, all of which are from different industries, and explore the location factors through case studies of each of them.

\section{Case study analyses of location factors}

Case of Headquarters-Production type: company E Company E (Figure 5), established in 1998, is located in Zhangjiang Hi-Tech Park. It is an enterprise specializing in the development, production, and sale of electric double layer capacitors and ultra-capacitors. Its ratio of $R \& D$ personnel reaches $20 \%$, and its $R \& D$ expenditure has reached $10 \%$ of total product sales. In addition to undertaking $R \& D$ activities in the $R \& D$ base, company $\mathrm{E}$ also carries out theoretical and basic research in cooperation with universities. It has a production center, a test center, a standardization center, an intellectual property department, and a project department in the R\&D base, and each task must be performed by professionals in all departments of the R\&D base. Consequently, proximity to an area with rich human resources becomes a key location factor for ensuring the efficiency of R\&D activities. Meanwhile, as a new energy storage device, the ultra-capacitor plays an important role in saving energy, and its development and popularization have enjoyed strong support from the government. Moreover, with the recent transfer of traditional manufacturing to middle and western China, Shanghai has issued a series of preferential policies to encourage enterprise to enter these new industries. Therefore, company $\mathrm{E}$ also focuses strongly on preferential policies, thus getting technological and financial support for the improvement of its innovation capability.

For company E, it does not only help to ensure demand for talent to be located in Zhangjiang Hi-Tech Park with rich human resources but also contributes to adopting an integrated management way to realize its commercialization. However, although company E regards rich human resources as a favorable factor, it does not think more about the importance of an $R \& D$ institution's proximity to universities or public research institutes due to well-developed transportation system and communication network in Shanghai. Moreover, the number of enterprises engaged in the production of ultra-capacitors is still relatively small in Shanghai; thus, company E pays more attention to its interaction with upstream and downstream enterprises than to industrial agglomeration. Furthermore, given the enterprise's growth and the rise in land costs in Zhangjiang Hi-Tech Park, company $\mathrm{E}$ will look for a new site with lower land costs nearby for its production base. When the R\&D institution becomes able to take on more R\&D programs, it will be considered to be separated from inter-firm organizations. This shows clearly the strong possibility that a separate organizational structure will be formed in company $\mathrm{E}$ 
because of the increasing $\mathrm{R} \& \mathrm{D}$ strength and investment inhibitions caused by rising land costs.

Case of Headquarters type: company $F$ Company F, founded in 1992, develops and produces high polymer materials and has become a leading enterprise in the Chinese plastic engineering industry (Figure 5). At first, its organizations were located in Shanghai. As the enterprise expanded, company $\mathrm{F}$ transferred its production plants outside of Shanghai, establishing new production bases in Hefei (Anhui Province) in 2006, Panjin (Liaoning Province) in 2008, and Chuzhou (Anhui Province) in 2009, while its R\&D institution and headquarters are still located in Shanghai. It has one central R\&D institute in Shanghai, close to the Minhang campus of Shanghai Jiaotong University, and more than $85 \%$ of the R\&D personnel hold Masters degrees, or higher or a senior professional title.

Company $\mathrm{F}$ attaches great importance to cooperation and joint research with universities. The universities near company $\mathrm{F}$ provide rich talents for its $\mathrm{R} \& \mathrm{D}$ activities. Meanwhile, as a leading enterprise in the same industry, company $\mathrm{F}$ also offers employment opportunities for graduate students. Although some changes have occurred in the location relationship of enterprise's organizations in company $\mathrm{F}$, the R\&D institution and headquarters are still located in Shanghai in order to track market trends and learn about new technologies and products from competitors. Besides, there are many enterprises within the industry which are located in Minhang District, which is favorable for the cooperation and competition between enterprises. Company F's R\&D institution is also close to Shanghai Zizhu Science-Based Industrial Park ${ }^{17}$, where there are many famous MNCs offering company $\mathrm{F}$ access to new technology. Another key point is that it has established customer network relationships with famous domestic enterprises and MNCs in Shanghai. This helps it keep in touch with customers in order to seize markets and adjust R\&D activities to meet market demands, while carrying out $\mathrm{R} \& \mathrm{D}$ at the present site.

Case of Production type: company G Company $\mathrm{G}$, set up in 1958, provides advanced high polymers for the production of fiberglass reinforced plastic and new materials. Its headquarters is situated in the Xuhui campus of the East China University of Science and Technology (ECUST) $)^{18}$ in Xuhui District, and its R\&D institution and production plant are located in Shanghai Chemical Industry Park ${ }^{19}$ in Jinshan District, in southwest Shanghai (Figure 5). It grew out of a school-run ECUST enterprise and has achieved innovation and recognition for its products through university-industry cooperation.
When company G was founded, all of its organizations were located in the Xuhui campus of ECUST. With the expansion of its production scale, the production plant was transferred to Shanghai Chemical Industrial Park. However, the long distance between R\&D and production seriously restricted the commercialization of the research results. In order to overcome the remaining barriers between $R \& D$ and production, the $R \& D$ institution was also transferred to its present site where the production plant is, while the headquarters and sales department remain at the original site for reasons of developing market and the inertial force of location.

Case of Independent type: company H Company $\mathrm{H}$, funded in 2004 , is an IC design company specializing in $R \& D$ in analog and mixed signal IC with primary focus on power management and LED driving products (Figure 5). It is situated in $\mathrm{CHJ}$, where there is a high concentration of electronics industry, including many upstream and down stream companies of IC production. Its parent company is located in $\mathrm{Wuxi}^{20}$, near Shanghai. The decisive factor for company $\mathrm{H}$ to be located in $\mathrm{CHJ}$ is the advantage of industrial agglomeration. Many related companies from within the industry as well as upstream and downstream industries are concentrated in $\mathrm{CHJ}$, making it easier to get information about new products and learn market trends in time. Consequently, company $\mathrm{H}$ can undertake targeted $\mathrm{R} \& \mathrm{D}$ activities and feed the R\&D results back to the parent company. We can see that the high possibility of learning market trends and carrying out R\&D activities according to market needs is an essential factor attracting company $\mathrm{H}$ to the location. However, although CHJ's advantageous location is acknowledged, life infrastructures (such as the public transport systems) need to be improved, in order to make work and life much easier and more efficient.

\section{Case of location change for R\&D institution: company}

I Company I, founded in 2000, is engaged in the R\&D and production of power automation devices and systems. Its departments are all located in Songjiang Industrial Zone. When company I was first established, its R\&D institution was located in $\mathrm{CHJ}$, while the headquarters and production plant were located in Songjiang. However, because of the pressure of rising rent in $\mathrm{CHJ}$, the R\&D institution was forced to transfer to Songjiang District, where the headquarters and production plant were located, thus forming the present HeadquartersProduction-R\&D organizational allocation type.

Sufficient land and R\&D-related human resources are regarded as the decisive location factors in $R \& D$ investment. It is easy for company I to ensure growing 
land demand in Songjiang District, given the lower land costs. In addition, being in close proximity to production plant helps facilitate the R\&D's commercialization. Nevertheless, though the company has more space for expansion in the suburbs than in the central city, the suburbs have some disadvantages, such as incomplete infrastructure, inconvenient transportation, and an unclean environment, that have negative effects on the development of the company. Especially serious are the occasional power outages caused by high power demands, which affect normal operations. Considering the talent factor, company I expects to move its $R \& D$ institution back to $\mathrm{CHJ}$, where there are more human resources than in Songjiang, but the possibility of rising costs is a major concern.

\section{Location factors for enterprise R\&D institutions on a local scale}

The main location factors affecting R\&D institutions' location patterns at local level include inter-firm, land, environmental, policy and institutional factors. Almost all enterprises attach great importance to close cooperation among inter-firm organizations. Most of the sample's manufacturing enterprises have established $\mathrm{R} \& \mathrm{D}$ institutions with other organizations in order to realize functional integration and the intensive use of land, factory building, and equipment; this is why the headquarters-production type of R\&D institutions is the most common. Of course, this allocation method is not the most efficient for all enterprises. As an enterprise grows and transforms within a changing environment, a reallocation of location and an organizational separation is certain to occur (as with companies F, G and I). According to our survey, in the process of organizational separation, close proximity to headquarters and the production plant is much more valued than proximity to other organizations for manufacturing $\mathrm{R} \& \mathrm{D}$ institutions. The reason why more $R \& D$ institutions are attached to headquarters is that much $\mathrm{R} \& \mathrm{D}$ activities are undertaken according to information or orders from headquarters. In order to shorten the time spent commercializing the $\mathrm{R} \& \mathrm{D}$ results, a correlation between $\mathrm{R} \& \mathrm{D}$ and production (as with company G) is emphasized. Nervertheless, along with the expansion of $R \& D$ activities and the strengthening of the $R \& D$ function, the original $R \& D$ institution will be separated from other inter-firm units, forming an independent R\&D institution, as was noted in the cases of companies $\mathrm{E}$ and $\mathrm{H}$.

Meanwhile, land cost and land scale have become important factors in the apparent suburbanization of
$R \& D$ institutions in manufacturing. Some surveyed enterprises were forced to relocate their $R \& D$ institutions due to the rising land costs or rents. For example, company I moved its $\mathrm{R} \& \mathrm{D}$ institution from $\mathrm{CHJ}$ in the central city to Songjiang District in the outer suburbs for rising land costs. Meanwhile, pressured by land costs and the land scale in urban cities, some enterprises, especially in the non-equipment manufacturing industries, choose to rent their production plants (as with company D) and even their R\&D sites.

Environmental factors are those elements in the cultural, economic, regulatory, and technological environments that affect economic development and regional image. Access to a wealth of hi-tech talent has become an important factor in the location choices of $\mathrm{R} \& \mathrm{D}$ institutions. For example, it is precisely the rich human resources in Zhangjiang $\mathrm{Hi}$-Tech Park that attracted company E. In terms of human talents, company I also hopes to move its R\&D institution back to $\mathrm{CHJ}$. However, it is notable that proximity to universities or research institutes is no longer regarded as the decisive factor because of Shanghai's complete transport system and well-developed communication network. Moreover, industrial agglomeration and close links with upstream and downstream industries are also important location factors for R\&D institutions in the manufacturing sector (as for companies $\mathrm{E}$ and $\mathrm{H}$ ). In addition, regional image, including government efficiency, power supply, public health and the environment, have also become important to an R\&D institution's location decision (as with company I).

Furthermore, with the gradual transfer of the manufacturing industry to beyond the central city or to other cities along the Yangtze River Delta, the preferential policy seems not to favor general manufacturing R\&D. Nevertheless, China has recently issued a series of preferential policies in support of $R \& D$ in rising industries, such as new energies and new materials, in order to improve resource efficiency. Meanwhile, the administrative division should take on much more responsibility for the location choices of $R \& D$ institutions. For example, enterprises think it necessary for government to provide detailed information about land use in potential R\&D locations. As the market grows, real estate developers and business owners will become suppliers or agents of R\&D sites. Consequently, the platform between the R\&D carrier and the supplier of $\mathrm{R} \& \mathrm{D}$ sites will help facilitate $\mathrm{R} \& \mathrm{D}$ efficiency. 


\section{Conclusions}

This article began by discussing the spatial distribution of enterprise R\&D institutions, with a focus on domestic enterprise R\&D institutions in Shanghai. The sample's non-manufacturing R\&D institutions are all located in the central city, while the suburbanization of manufacturing $\mathrm{R} \& \mathrm{D}$ institutions in Shanghai is obvious, indicating that the functional division of the urban city is correlated with the industrial division. Moreover, the high concentration of enterprise $R \& D$ institutions in industrial zones and hi-tech parks shows an increasing decentralization, presenting industrial differences among the different concentration districts. Moreover, the concentration of $R \& D$ institutions created by foreign capital is much stronger than that of institutions created by domestic capital, and they are more inclined to locate in industrial zones and hi-tech parks with complete infrastructures and stronger competitiveness. A reason for this is that early investment preferential policies in industrial zones attracted many foreign enterprises; also, many MNCs $R \& D$ institutions can pay the higher cost for getting an advantageous location.

Secondly, the sample enterprise R\&D institutions in the manufacturing sector are classified into four types according to the location relationship between R\&D institutions and other organizations: the HeadquartersProduction, Headquarters, Production, and Independent R\&D institution types; among these the HeadquartersProduction type is the most common, followed by (in descending order) Headquarters type, Independent R\&D institutions, and Production type. There are distinct industrial differences among the four types. These industrial differences not only lead to different location relationships between $\mathrm{R} \& \mathrm{D}$ institutions and other organizations but also result in the diversity in the $R \& D$ institutions' location patterns. Headquarters type and Production type R\&D institutions are mainly located in suburban areas, while the location pattern of Headquarters type R\&D institutions is similar to that of Independent $\mathrm{R} \& \mathrm{D}$ institutions, with a distribution across industrial zones and hi-tech parks inside the outer ring road. As for Headquarters type R\&D institutions, most of their production plants are located in cities other than Shanghai, which means their production functions will be transferred to cities other than Shanghai as their enterprises grow.

Lastly, the article explores the local location factors that effect R\&D institutions' location types and location patterns through case studies. It finds that most enterprises attach importance to the cooperation among all inter-firm organizations. At present, HeadquartersProduction type R\&D institutions are the main allocation vehicles for domestic enterprises in Shanghai. However, this allocation method is not the most efficient choice for all enterprises. Land costs and land scales in urban cities have become important factors in the reallocation and suburbanization of R\&D institutions. From the surveys, we can forecast that the tendency towards the separation of headquarters, production sectors, and R\&D institutions will become more evident for limited land use scales. While considering the land factor, R\&D institutions' location choices will not be restricted on the enterprises' own estates (including factory building and workshops), and new R\&D location choices, such as renting laboratories or instruments and equipment, will be more frequent. Therefore, it is necessary for government to build a platform between suppliers of $R \& D$ sites and $R \& D$ carriers to provide detailed information on the proposed sites or buildings of $\mathrm{R} \& \mathrm{D}$. Moreover, though talent plays an important role in $\mathrm{R} \& \mathrm{D}$ location, it is not necessary for a local R\&D institution to be close to a university or R\&D institute given Shanghai's highly developed transport and communication system; this seems different from the national situation. Therefore, enterprises generally opt for a region with rich human resources at the national level when establishing their R\&D institutions; but for enterprises in metropolitan areas as in Shanghai with rich talent, they must improve themselves, strive to excel, and thus attract excellent talent at the local level. Furthermore, $\mathrm{R} \& \mathrm{D}$ institutions represent advanced technology and knowledge and the voice of request for suitable R\&D environment can be heard, which turns the regional image into another important factor to be considered.

In fact, the location types and location patterns of enterprise $\mathrm{R} \& \mathrm{D}$ institutions differ across different cities and are always changing. The location factors given attention also vary according to the enterprise's strategy, industrial features, and products. Therefore, in order to learn about the dynamic changes in location patterns for enterprise $R \& D$ institutions, it is necessary to do further research, using the present findings. In addition, the questions of whether the location types of enterprise $\mathrm{R} \& \mathrm{D}$ institutions in other cities are similar to those in Shanghai and what location features are present in other cities remain for future discussions.

\section{Acknowledgements}

A summary of this paper was presented at the 5th 
Japan-Korea-China Joint Conference on Geography at Tohoku University in November 2010. The author is grateful to the surveyed enterprises that gave their cooperation to the interview surveys and would like to thank Professor Yoshida and Professor Ishizaki of Nara Women's University for their valuable advice on this study. The author also extends thanks to Professor Wang Chengyun of Shanghai Normal University for her study support.

\section{Notes}

1. In this article, we use one name of $R \& D$ institutions to define the departments being engaged in R\&D activities. Not only the research institutes or branch corporations specializing in $\mathrm{R} \& \mathrm{D}$ as independent economic entities, but also the R\&D departments as a part of the enterprise are included in enterprise $R \& D$ institutions.

2. Shenzhen is a major city in Southern China, situated immediately north of Hong Kong. The area became China's first Special Economic Zone. Being southern mainland China's major financial center, Shenzhen is home to the Shenzhen Stock Exchange as well as the headquarters of numerous high-tech companies.

3. Hangzhou is the capital and largest city of Zhejiang province in eastern China. A core city of the Yangtze River Delta, its position on the Hangzhou Bay, 180 kilometers southwest of Shanghai, gives it economic power. It is an industrial city with many diverse sectors (such as in light industry, agriculture and textiles), and is considered an important manufacturing base and logistics hub for coastal China.

4. Qingdao is a major city in eastern Shandong Province, Eastern China. Lying across the Shandong Peninsula while looking out to the Yellow Sea, Qingdao is a major seaport and industrial center, and is perhaps best known for its Tsingtao Brewery. It is also home to Haier, a large household appliances manufacturer, and Hisense, a major electronics company.

5. Suzhou is a major city located in the southeast of Jiangsu Province, in Eastern China, adjacent to Shanghai. It is situated on the lower reaches of the Yangtze River and is a part of the Yangtze River Delta region. Suzhou is one of the most prosperous cities in China and is home to many high-tech enterprises.

6. In August 2009, Nanhui District merged into Pudong New area, and Shanghai was divided into 18 county-level divisions. However, the distribution of R\&D institutions is analyzed according to the former administrative divisions, still in effect when the survey data was collected.

7. Large and medium-size industrial enterprises must meet the following conditions: they must have more than 300 employees, sales of more than 30 million yuan, and total assets of more than 40 million yuan. Large-scale enterprises must have more than 2000 employees, sales amounts of more than 300 million yuan, and total assets of more than 400 million yuan.

8. Caohejing Hi-Tech Park (CHJ), emerged from the early industrial park of Shanghai Caohejing Microelectronics established in 1984, is situated to the southwest of downtown Shanghai. It is one of the first state-level economic and technological development areas and high-tech industrial zones in China to be engaged mainly in attracting foreign capital, introducing advanced technology from abroad, and developing high and new technology. More than 20 universities and colleges and over $120 \mathrm{R} \& \mathrm{D}$ institutions are located nearby. Now it specializes in the development of computer hardware and software, integrated circuits, microelectronics, communications and bioengineering technology.
9. As a national university science park, the East China University Science and Technology Park (ECUST Park) was founded in 2003. Its core competencies are in the fields of fine chemical, biopharmaceutical, and new materials industries. It includes an R\&D center in the south of Xuhui District, a universal incubator at the East China University of Science and Technology in Xuhui District, and an industrial base in Shanghai Chemical Industry Park, located at the boundary of Jinshan District and Fengxian District.

10. Zhangjiang Hi-Tech Park, founded in 1992 as China's state-level high-tech industrial development zone, is located in the middle of Pudong New Area, comprising the Technical Innovation Zone, the Biomedicine Industry Zone, the IC Industry Zone, the Scientific Research and Education Zone, and the Residential Zone. In 1999, Shanghai's Municipal Committee and Municipal Government issued the "Focus on Zhangjiang" strategy and identified the IC industry, the software industry, and biomedicine as the leading industries on behalf of which the park could play a leading innovative role. Zhangjiang has been developing rapidly ever since.

11. Shanghai Xinzhuang Industrial Zone, established in 1995, is situated in Minhang District, with an area of $13.65 \mathrm{~km}^{2}$. It is adjacent to the central city of Shanghai, enjoying an advantageous location and convenient transportation. There are about 26 universities, colleges, and research institutes near the industrial zone, which provide high quality talent and technology for enterprises.

12. Songjiang Industrial Zone is the first municipality-level industrial zone in Shanghai's suburbs. It is situated in Shanghai's southwest, 25 kilometers away from Hongqiao International Airport and 68 kilometers away from Pudong International Airport. The Shanghai-Hangzhou expressway also runs across Songjiang Industrial Zone.

13. The term "same location" here means the same site or spot, not the same region or area.

14. In this article, independent enterprise R\&D institutions include not only independently owned companies specializing in $\mathrm{R} \& \mathrm{D}$ for the purpose of providing technology and technical services to parent or other companies but also the enterprise R\&D institutions located on sites that are independent of other organizations.

15. The locations of all the case companies are shown in Figure 5.

16. Changzhou is a prefecture-level city in the southern Jiangsu province of China. It is located on the southern bank of the Yangtze River and lies 160 kilometers west of Shanghai and 110 kilometers southeast of Nanjing.

17. Shanghai Zizhu Science-Based Industrial Park, founded in 2001, is situated in the southeast of Minhang District. It consists of University Park, an R\&D base and the Zizhu Peninsula. The University Park consists mainly of Shanghai Jiao Tong University and East China Normal University. The leading industries of the $\mathrm{R} \& \mathrm{D}$ base are micro-electronics, software engineering, digital media technology, and aerospace technology.

18. East China University of Science and Technology (ECUST), originally named East China Institute of Chemical Technology, was founded in 1952. The university has accomplished much in technical transfers and cooperation among industry, university, and research. ECUST Park relies on the rich academic resources of this university.

19. Shanghai Chemical Industrial Park lies on the north coast of Hangzhou Bay with a total planning area of $29.4 \mathrm{~km}^{2}$. It is located south of Shanghai, on the boundary between Jinshan District and Fengxian District. As a top chemical base in Asia, it has attracted many enterprises in the fine chemical, biomedical, and new materials industries. 
20. Wuxi is a city in Jiangsu province. It borders Changzhou to the west and Suzhou to the east. Wuxi is also dubbed "little Shanghai" because of its close proximity to the city, rapid urbanization, and booming economy.

\section{References}

A.T. Kearney Global Business Policy Council (GBPC). 2010. Investing in a rebound: The 2010 A.T. Kearney FDI confidence index. Vienna, U.S.A: A.T. Kearney, Inc.

Audretsch, D. B. and Feldman, M. P. 1996. R\&D Spillovers and the geography of innovation and production. The American Economic Review 86: 630-640.

Autant-Berard, C. 2006. Where do firms choose to locate their R\&D? A spatial conditional logit analysis on French data. European Planning Studies 14: 1187-1208.

Cantwell, J. 1995. The globalization of technology: What remains of the product cycle model? Cambridge Journal of Economics 19: 155-174.

Creamer, D. 1976. Overseas research and development by United States multinationals, 1966-1975. New York: The Conference Board.

Dong, L. 2007. The agglomeration characteristics of corporation's $R \& D$ facilities in Shanghai. Master's thesis, Department of Urban and Regional Economy, East China Normal University. (C)

Du, D. 2001. Location models of MNCs's R\&D globalization by MNCs. Shanghai: Fudan University Press. (C)

Du, D., Sun, Y. and Sheng, L. 2010. The spatial distribution and location trends of the R\&D labs by multinational corporations in China. World Regional Studies 19: 1-13. (CE)

Dunning, J. H. 2000. Regions, globalization, and the knowledgebased economy. Oxford: Oxford University Press.

Fields, G. 2006. Innovation, time, and territory: Space and the business organization of dell computer. Economic Geography 82: 119-146.

Florida, R. 1997. The globalization of R\&D: Results from a survey of foreign-affiliated R\&D laboratories in the USA. Research Policy 23: 85-103

He, Q. and Wang, Z. 2006. Study on the location factors of overseas $\mathrm{R} \& \mathrm{D}$ investment in China. China Soft Science Magazine 7: 113-120. (CE)

Ishigami, T. 1986. Kigyou kenkyuusyo no ritti doukou (Location trends of enterprises research institutions). JDB Research Report 90: 2-43. (JE)

Jones Lang LaSalle. 2008. China business parks: The next real estate opportunity. In World winning cities: Global foresight series 2008. Chicago: Jones Lang LaSalle, Inc.

Kato, K., Iwasaki, Y. and Aichia, M. eds. 1996. A study on location factors of the private research institute location: Based on logit model of disaggregate behavioral analyses. Journal of Infrastructure Planning and Management (JSCE) 13: 241-246. (JE)

Kimura, T. 1990. Wagakuni no kougyou ni okeru seisan kinou no chiiki bunka: R\&D kinou no ritti ni chumoku shite (Regional differentiation of industrial production function in Japan: From the location of R\&D function). In Sangyou kuukan no dainamizumu: Kouzou saihenki no sangyou ritti tiiki shisutemu
(Dynamism in industrial space: Industrial location and regional System during reorganization), ed. $\mathrm{H}$. Nishioka and $\mathrm{K}$. Matsuhashi, 72-84. Tokyo: Taimeido. (J)

Kuemmerle, W. 1999. Foreign direct investment in industrial research in the pharmaceutical and electronics industries: Results from a survey of multinational firms. Research Policy 28: 179-193.

Leonard, L. 1986. Locating corporate R\&D facilities, Report No.892. New York: The Conference Board, Inc.

Lin, J., Science and Technology Commission of Shanghai and Shanghai Municipal Statistics Bureau. 2007. Shanghai statistical yearbook on science and technology 2007. Shanghai: Shanghai Popular Press. (C)

Liu, Y. and Liu, W. 2007. Study on regional differentiation of R\&D localization of TNCs in China. Economic Geography 27: 231225. (CE)

MLIT (Ministry of Land, Infrastructure and Transport). 2006. White paper on national capital region development (2006). Tokyo: Ministry of Land, Infrastructure and Transport.

Nakagawa, T. 1996. Location patterns of private research institutions in Japan. Studies in Human Geography XX: 145159. (JE)

Nakagawa, T., Ji, Z., and Suyama, S. eds. 1992. Agglomeration of private research institutions in Tsukuba science city. Japanese Journal of Human Geography 44: 643-662. (JE)

National Bureau of Statistics of China. 2006. Special investigations report on enterprise innovation. http://finance.sina.com.cn/ roll/20061023/0000991021.shtml (last accessed 2 December 2011).

Niosi, J. 2003. The location choices of R\&D activities in Canadian multinationals. International Business 8:141-157.

Nishioka, H. and Matsuhashi, K. 1990. Sangyou kuukan no dainamizumu: Kouzou saihenki no sangyou ritti tiiki shisutemu (Dynamism in industrial space: Industrial location and regional system during reorganization). Tokyo: Taimeido. (J)

Oda, K. and Saso, J. 1987. Kenkyuusyo no ritti youin to chihou ritti ni tsuite: Minkan kenkyuusyo no ritti ni kansuru kenkyuu (Study on location factors of research institutions: Case on the location study of private research institutions). Papers on City Planning 22: 187-192. (JE)

Osaka Prefecture Institute for Advanced Industrial Development. 2007. Kigyou ni okeru kenkyu kikan no setti joukyou (kenkyuu houkokusyo) (Research report of establishment of enterprises' institutions). Osaka: Osaka Research Center for Industry and Economy. (J)

Pearce, R. D. 1989. The internationalization of research and development by multinational enterprises. New York: St. Martin's Press.

Porter, M. E. 1986. Competition in global industries. Boston: Harvard Business Press.

Robert, R. 1977. Research and development abroad by U.S. Multinationals. New York: Praeger.

Sato, Y. 2004. Migration processes of R\&D workers in Tsukuba science city: A case study of the pharmaceutical industry. Annals of the Japan Association of Economic Geographers 50: 205-226. (JE)

Shanghai Private Economy Development and Promotion Center. 2006. Entrepreneurship, innovation, creation: Report of 
Shanghai private enterprises' innovation. Shanghai: Shanghai Scientific and Technological Publishing House. (C)

Sun, Y. 2003. Strategic or tactical? Foreign research and development in developing countries: A case study of China. Asian Geographer 22: 143-167.

Walker, R. 1988. The geographical organization of productionsystems. Environment and Planning D: Society and Space 6: 377-408.

Wang, C. and Du, D. 2007. R\&D investment motives and location selection by Japan in China. Economic Tribune 17: 65-67. (CE)

Wang, P. 2007. The types of location of foreign R\&D in Shanghai. Master's thesis, Department of Urban and Regional Economy, East China Normal University. (C)

$\mathrm{Xu}, \mathrm{R}$. and Du, D. 2004. Study on the location of foreign capital
R\&D in Shanghai. Economic Geography of China 24: 625-628. (CE)

Xue, L., Shen, Q. and Wang, S. 2002. Multinational R\&D in China under the background of globalization: An analysis based on the industrial differences of multinational independent $\mathrm{R} \& \mathrm{D}$ institutions in China. Management World 3: 33-42. (CE)

Zhang, R. and Du, D. 2006. On the spatial difference and the regional classification of R\&D industry in China. Areal Research and Development 25: 20-24. (CE)

(C): written in Chinese

(CE): written in Chinese with an English abstract

(J) written in Japanese

(JE): written in Japanese with an English abstract 